International Journal of Engineering \& Technology, $7(3.14)(2018) 336-339$
International Journal of Engineering \& Technology
Website $: \frac{w w . s c i e n c e p u b c o . c o m / i n d e x . p h p / I J E T}{2}$
Research paper

\title{
Video Blog Advertising: Feedback Analysis
}

\author{
M.V. Gundarin1, A.I. Zotova2, I.Y. Ilina3, E.E. Nakhratova4, I.V. Makarova5 \\ 1-4Russian State Social University \\ W. Pieck St., 4, bld. 1, Moscow, 129226, Russia \\ 5 Moscow Polytechnic University \\ P. Korchagina St., 22, Moscow, 129626, Russia
}

\begin{abstract}
In recent years, a new market trading in cryptocurrencies and instruments based on them has been formed. The market of this paper The Internet, as a result of the gradual development of information technologies, has become an advanced communicative means resulting in totally new communication forms. At this stage of development, Internet technologies promote social growing-up of a person in communities. At this point in the history of the Internet, we face the problem of studying the social aspect of virtual reality. Participants in social and political processes have shown their interest in investigating the Internet phenomenon, including its role in different spheres of public life, since the moment of its formation. Such communicative means as video blogs are of key importance. The urgency of this issue is multifaceted. Thus, the article presents results of the content analysis of the target audience feedback referred to video blog advertising. The findings enable to optimize advertisers' use of such channel of promotion as video blogs.
\end{abstract}

Keywords: video blog, advertising, content analysis, advertising integration format, target audience.

\section{Introduction}

To define key formats for integration of advertising into video blogs and their peculiarities is currently important as buyers are gradually diverging from traditional models of media content, such as TV [20]. Online videos gain in popularity. So, advertisers are to follow their target audience and master new advertising formats [13] by rendering information services [21]. Vlog advertising has some advantages over traditional ad placement, such as $\mathrm{TV} /$ public places, in terms of relative novelty in the ad integration format. It means that, probably, this ad form is not as irritating and annoying for the target audience as traditional ad placement channels. Besides, the current popularity of video bloggers, who are trend setters and leaders for the relevant target audience, means that proper vlog advertising can be rather effective [3].

Video blogs (or blogs) are an important constituent of the Internet media today. The audience of the most popular bloggers in Russia and abroad equal to tens of millions of people. But blogs are also a symbolic phenomenon of the Internet marketing. Bloggers make heavy use of different ad tools to earn money and to convey information, paid by the customer, to the audience. For today, their advertising budgets are comparable with the "traditional" mass media.

Ad integration into a video blog is a new and poorly studied phenomenon. It is an additional spot marketing tool, which is not always necessary to be included in the advertising campaign. Generally, more traditional tools of online advertising, such as context or targeting advertising [15], are optimum and preferred for many advertisers when choosing the online promotion way. Although vlog advertising is rather an optional tool of promotion, it has a system of integration ways/formats, each of which has own features and purposes. It should be noted that, unfortunately, at the moment there is no scientific literature or textbooks on this topic. So, we cannot speak about definite or final ways of integration. A lot depends on a creative approach, that's why new formats are in development, and experiments are conducted in this field. And one cannot call the list of integration ways a "final" one.

Video blogs are used for advertising due to ad market oversupply, which promotes advertisers to master new ad placement channels, namely, the Internet [9]. As the vlog ad format is relatively new, it is not finally developed so far: there are no clear integration formats with detailed description; there are no clear evaluative criteria for ad campaign efficiency [23]; cooperation agreements are concluded between advertisers and video bloggers unofficially resulting in an unfair attitude to the deal by both parties, lack of liability, warranties, failure to meet deadlines, changing prices in the vlog ad market, etc.

As mentioned above, "instead of "the barrier of mistrust" to newspapers, TV, etc., the blogosphere threatens with "the syndrome of betrayed trust". If a blogger is caught in a lie or audience opinion manipulation, the value of his or her blog as a source of information will drop more as compared to the similar situation in "the traditional media" [19]. The first Russian video blogger online marketplace Vlogster is to reduce advertiser and blogger cooperation risks; it is the intermediary at concluding official contracts between them. Just the site of this marketplace specifies the key formats of ad integration (product mention and review, activation announcement, participation in activation, special release and product placement) that made the basis for our research. The analysis of the above-mentioned formats made it possible to identify the peculiarities of this process [4]. 


\section{Methods}

Content analysis was used as a basic ad research method. It allowed determining objective links among ad content, its characteristics and influence on potential consumers. Note that video bloggers avow that they carefully study users' comments. "I was really inspired by immediate feedback: you read comments and understand what people like, and think out a new release", says a famous business blogger Dmitry Portnyagin [11, 18].

\subsection{Target of the Research}

was to determine the evaluation characteristics of integrated ads by analyzing feedback of the vlog target audience.

In average, 10 vlogs for each ad integration format, specified on Vlogster.ru, were selected to conduct the feedback content analysis. All videos were mainly taken from this site, and in case of deficiency - from YouTube.

The following characteristics of vlogs were analyzed: title; author; number of followers; topic (description); number of reviews, number of likes and dislikes; number of comments; publication date; average review time; approval level; target audience; integration features.

It should be noted that vlogs with maximum 150 comments had been analyzed completely, that is, almost all comments were grouped. In most cases, if number of comments exceeded 150, only comments showing the attitude of the target audience to the integrated advertising were grouped. Thus, comments from 48 video blogs were subject to content analysis.

\subsection{Research Tools}

were as follows: content analysis classifier; content analysis form; instructions for the researcher in charge of registration and coding of units of count; catalogue (list) of analyzed documents.

\subsection{Units of Analysis}

were units of meaning showing the positive and negative attitude of the vlog target audience to the integrated advertising. It is important to understand that one comment may include several units of meaning, ideas reflecting different aspects of attitude to the integrated advertisement.

\subsection{Units of Count}

Was the number of units of analysis in pieces

\section{Indicators}

were the words showing obvious positive attitude (cool/great/keen, etc.) and negative attitude to vlog advertising (gross/rubbish/garbage, etc.); all comments with a word "advertisement" and such words as "unsubscribing", "sold out", etc. showing the reaction to vlog advertising; words and expressions showing desire to buy advertised goods, for instance "want the same", "where to buy", etc. [5]. During the analysis, we took ideas of the comments, their conceptual meaning. Comments without meaning, which did not refer to a video or were difficult to understand due to the senders' poor knowledge of Russian, were rejected.

\section{Results}

In the course of the content analysis of vlog comments, we have received data characterizing the evaluation of the integrated advertising and attitude thereto.

\subsection{Activation Announcement}

is the format used when a blogger informs his or her audience on the start of any contest or special discounts/promos, future events, and reminds on ongoing contests/discounts/promos, which were mentioned in previous videos.

The results of the content analysis of comments to the mentioned blogs show that if a blogger uses this format often, confidence in him declines sharply. In this format, the audience are too sensitive to video content. Often, the target audience feel that a blogger tries to deceive them. If the whole video content is rather weak, they suspect that a video was made only for the advertisement [17]. It concerns even those cases, when the quality of a video is perfect, there is a plotline making it similar to a minifilm. The audience do not take the bait offered by the advertiser; they are always ready to find a trick and search for alternatives to advertised goods, etc. In such case, the most advantageous are either videos, which do not attract too much attention to advertised goods, but to the topic that may be indirectly connected thereto, or videos that "catch" with live emotions, positive attitude and humor with unique coverage of an event. While viewing a "catching" video, negative emotions can go away and can be covered by positive feelings, and ideally the audience will associate these new emotions with advertised goods [2].

\subsection{Product Review}

is the format used when a blogger provides detailed information on the key characteristics of the advertised goods, their competitive features, advantages and sometimes disadvantages, main functions [14].

As this format provides for the coverage of product key functions, it is important to understand this process. Different goods require different review aspects. For example, reviews of technical appliances, different devices are to be made by a competent person. Many advertisers make a mistake. They think that it is enough to give a device to a male blogger (a popular one is preferable) to review and success will come automatically, for instance, sale growth. But the analysis showed that the audience were rather discerning and competent, and the unfair review would brush them off. The point is that the audience become more demanding with market expansion and increased number of reviewers. The audience need to see visual evidence of good product features; it will not take reading the text from a piece of paper and the blogger's ignorance of special terms, etc. The advertisement should be distinguished by sincerity, fairness, professionalism. Viewers may have negative attitude to product testing, if a blogger chooses the easiest way and slacks his work. So, the biggest mistake of the blogger in the depilatory cream vlog was that she applied cream to the hand, where there was almost no hair. It was far from reality; a review lost its meaning and audience trust along with it. Reviewers are to show the intended function of the product and no play to the camera. But the advertisers have a loophole in this format: if they send goods for review to bloggers, who normally use this format, such integration will be almost invisible. It is important to hit into the channel content with the product category. For instance, beauty bloggers usually review cosmetics in the categories My Favourites/Likes, etc.; sportsmen can review gyms, sport nutrition, clothes, etc.; gamers review new computer games, mobile applications, etc. Thus, it will be difficult for viewers to find ad with a naked eye; it is easier to find it, when one and the same product is advertised by a great number of different bloggers.

\subsection{Special Release}

is the most expensive and large-scale project, implemented by any famous company having enough resources and involving different bloggers. In special releases, advertised goods can be shown to the audience from a new side and buyers will know more about the product. 


\section{Discussion}

The analysis shows that high quality content both from conceptual and technical points of view is important in the frames of this vlog ad integration format. Often, a video blogger applies to entertainers, as they make video for him/her, he/she becomes a model or is involved in reality shows, etc. If a blogger still remembers about his/her audience, makes special videos about the project on his channel, shares his/her opinion, the advertisement is unlikely to be violently opposed. Most of all, the audience like the reality show and travelling format. And mix is the best way. Earning the confidence of viewers requires big investments in this format, but in future it will have positive impact on the target audience loyalty and company image. The target audience are interested in special releases having a definite mission related to the solution of any public or social issues. Special releases, which are difficult to distinguish from standard product reviews, are unwanted. It is important to inflame the audience and not just to tell something. In this format, the entertaining content is ranked first, but not the informative one.

\subsection{Product Mention}

is the format used when a blogger tells name of the product, demonstrates it to the camera, makes reference to its characteristics, features (one or two), links to the product in the description under a video that can be used to buy a product, or web links/links to groups in the social networks. The above characteristics can be combined in one video. At that, links in the description are usually combined with other characteristics.

The findings show that in the framework of this format, the target audience should see that a video was not made just for advertising. If one video includes more than three integrations, it won't be long before the negative reaction. Herein, a very good example is videos, which don't advertise the product directly. That is, they don't apply all tools at once (logo, brand name, brief characteristics of the goods, etc.). And the main idea of a video is indirectly related to the advertised goods by association. It should be noted that product mention is very much the same as activation announcement with regard to perception.

\subsection{Participation in Activation}

is the format when a blogger informs his/her audience on the start of any contest/promo and participates him/herself in this contest/promo, shows how to solve tasks in hand.

The comments' analysis shows that from the audience's point of view, participation in activation is the most receptive format. Each blogger has a unique opportunity to stand out, to stick in memory, and to present him/herself in a different way. If the creative approach and quality of a video are high, the audience easily forget that it is an advertisement first. The advantages of participation in activation are as follows: a blogger can involve the audience by his/her participation in a contest. Sometimes, videos become viral and are spread in the social networks as examples of perfect advertising. Advertisers conducting a contest game/challenge/relay/flash mob may account for a huge positive effect. Contests based on insight/association with the product, where choice of a participating blogger hits the target audience of the campaign (the audience accept a blogger as a trendsetter/leader), are taken well. If a blogger does not ask to vote for him/her and just sets a good example for others to follow, it prepossesses the audience even more in his/her favour and in favour of advertised goods.

\section{Conclusion}

Technical progress provides for the expansion of the target audience of many companies in the Internet, which became an alternative to traditional channels of media content placement $[8,10]$. Thus, new video advertising placement channels were required. The topicality of this work is that it covers such promising and modern area of online ad placement as video blog advertising. Nowadays, such advertising format is already used by many advertisers as an additional one in the framework of advertising campaigns. For some goods, vlog advertising is the most efficient promotion. In general, the research results prove that special release and participation in activation are the most perceptible formats of vlog advertising. The reasons are as follows: high creativity level, insights, the entertaining character of a video, quality content both at conceptual and technical levels, relatively high resource consumption [1]. Excessive advertisement in one video, frequent ad integrations into several vlogs at a run, low quality content, lack of creativity and honesty, the blogger's incompetency in one or another issue related to advertised goods - all these facts only irritate the audience and arouse negative emotions. It was found out that in some cases, in spite of high percentage of video likes, comments contain a high share of negative feedback. Based on the findings, we may conclude that:

1. When integrating advertising into video blogs, it is important to find the insight, to spread the desire to buy the product over the target audience, to make viewers feel the taste/flavor/texture of the product on the other side of the screen. Such methods are effective as related to the young audience;

2. Video bloggers involved in vlog advertising become the company's advertising personalities for some period. Advertised goods will be associated with their personal qualities. A company should find such blogger, whose values coincide with the ones of a corporate advertiser;

3. If vlog advertising is based upon the competitive format, both monetary price and nonfinancial incentives should motivate the target audience to participate therein. For example, a contest is to be inspiring, interesting and fashionable to some extent (it can be a popular flash mob/relay/challenge, etc.);

4. Advertisers should not cheat the audience. Sometimes product imperfections are worth mentioning, but in such case one should focus on the unique features of a product, which could overshadow the drawbacks of the product;

5. The advertised product can be seen on the screen during the whole video, if it is a product review. In other cases, longterm presence of the product on the screen is not recommended, otherwise it should be justified in any way;

6. Ideally, a viewer should not think that a video is produced with the advertising purpose only. For example, when integrating ads into a video with life hacks, hacks should be important and practical. General phrases are prohibited. If a product is to eliminate any problem, a blogger should be its carrier.

In conclusion, it is worth mentioning that nowadays a lot of information falls on a person. Modern society can be characterized as the information society, where information is the main wealth [16]. The objective law of development of such society is the intense information processes: increased message transfer rates, transferred information volumes and information processing. Technological development implies the strengthening of the role of human capital, as only with qualified work force the state can implement all innovations promoting the effective functioning of the economy in the current concept $[6,7,12,22]$. 


\section{References}

[1] A.N. Awan. Virtual Jihadist Media. Function, Legitimacy and Radicalizing Efficacy. European Journal of Cultural Studies, 10(3), 2007, pp. 389-408.

[2] V.N. Garkusha, M.E. Kudryavtseva. Possibility of Creative Approach in Building Advertising video for High-Tech Field. Information-Communication-Society, 1, 2016, pp. 35-39.

[3] E. Gordon, G. Koo. Placeworlds: Using Virtual Worlds to Foster Civic Engagement. Space and Culture, 11(3), 2008, pp. 204-221.

[4] M.V. Gundarin, E.A. Korycheva. Product Placement v blogosfere [Product Placement in the Blogosphere]. PR i reklama v izmenyayushchemsya mire: Regionalnyi aspekt: sbornik statei [PR and Advertisement in the Changing World: Regional Aspect: Collection of Articles]. Barnaul, 2016.

[5] M.B. Holbrook. The Consumption Experience-Something New Something Old, Something Borrowed, Something Sold: Part 2. Journal of Macromarketing, 27(1), 2007, pp. 86-96.

[6] I. Ilina, E. Kryukova, E. Potekhina, I. Shadskaja, E. Abyzova. Russian Lectures at the Crossroads of Reforms: Strategies of Survival and Adaptation. European Research Studies Journal, 20(2), 2017, pp. 86-97.

[7] I. Ilina, A. Zotova, E. Kuznetsova, E. Nakhratova, E. Kryukova Teachers of Russian Higher Educational Institutions in the Professional Labor Market. Rupkatha Journal on Interdisciplinary Studies in Humanities, 8(2), 2016, pp. 128-136.

[8] S.B. Ilyashenko, I.S. Lebedeva. Main Directions of Increase in Efficiency of Electronic Commerce. Actual Problems of the Humanities.Vienna. Monograph, 4, 2016, pp. 69-80.

[9] N. Kasyanova. Structural and Substantive Features of Corporate as an Open Hypertext Space. Young Science, 1(5), 2014, pp. 41-44.

[10] V.I. Kataeva, O.V. Kaurova, S.V. Koludarova, J.O. Sulyagina, T.V Fomicheva, E.M. Kryukova. Barriers of Inequality in Social Institutions of Russia. Biosciences Biotechnology Research Asia, 12(3), 2015, pp. 2813-2820.

[11] A.V. Kovaleva, D.I. Belousova. Formaty, formy i struktura reklamy $\mathrm{v}$ videoblogakh [Formats, Forms and Structure of Advertising in Video Blogs]. PR i reklama $v$ izmenyayushchemsya mire: Regionalnyi aspekt: sbornik statei [PR and Advertisement in the Changing World: Regional Aspect: Collection of Articles]. Barnaul, 2016.

[12] E. Kryukova, N. Starostenkov, S. Krapotkina, E. Timoshina, D Makeeva, T. Yudina. Socio-Economic Problems of Today's High School Students in the Context of Reforming the Educational System of the Russian Federation. Journal of Advanced Research in Law and Economics, 7(2), 2016, pp. 287-293.

[13] Yu.M. Melnik, L.Yu. Saher, N.S. Illiashenko, Yu.M. Ryazantseva Classification of Basic Forms and Types of Marketing On-Line Communications. Marketing i menedzhment innovatsii, 4, 2016 , pp. 43-55.

[14] E.E. Nakhratova, I.Y. Ilina, A.I. Zotova, M.S. Stepanov, S.V. Dusenko. Modern Peculiarities of SWOT Analysis When Taking Management Decisions by Russian Top Managers. International Journal of Applied Business and Economic Research, 15(8), 2017, pp. 187-194.

[15] N.G. Nesterova. Radio Text as Hypertext. Vestnik Tomskogo gosudarstvennogo universiteta. Filologiya, 5, 2015, pp. 89-99.

[16] E.A. Plekhanova, I.Y. Moiseeva. The Development of Mass Media in the Modern Information Society. European Social Science Journal, 5-1(44), 2014, pp. 408-414.

[17] A.A. Prikhodko, L.V. Yushkova. Modification of Paradigm for Advertising and Public Relation Activities within the Context of Intensive Development of Social Media. Informatsionnye tekhnologii i matematicheskoe modelirovanie $\mathrm{v}$ ekonomike, tekhnike, ekologii, obrazovanii, pedagogike i torgovle, 5, 2012, pp. 8-11.

[18] R. Sadykova. Kamernyi uspekh: kak sdelat populyarnyi videoblog o biznese [Chamberlike Success: How to Make a Popular Business Video Blog]. 2017. Available online: www.rbc.ru/own_business/01/06/2017/592ebdcf9a7947de7881445 2

[19] A.L. Shilovskaya, S.J. Starodumova, M.A. Volkova, P.V. Zhesterov. The Judicial Practice of the European Court in the Sphere of Non-Material Reputational Harm. Man in India, 96(12), 2016, pp 5635-5645.

[20] E.L. Vartanova. Constructing Russian Media System in the Context of Globalization. World of Media. Yearbook of Russian Media and Journalism Studies, 3, 2013, pp. 9-36.

[21] M.A. Volkova, L.B. Sitdikova, S.J. Starodumova, A.L. Shilovskaya. Legal Problems of the Information Services Implementa- tion in Russian Civil Law. Review of European Studies, 7(6), 2015, pp. 273-281.

[22] V.M. Zaernjuk, E.M. Kryukova, E.V. Bokareva, L.I. Chernikova. A Study of the Theoretical Approaches to the Banking Financial Intermediation and its Development Trends. World Applied Sciences Journal, 30(12), 2014, pp. 1723-1725.

[23] P.V. Zhesterov, A.A. Neznamova, S.J. Starodumova, M.A. Volkova, R.R. Lenkovskaya. The Legal Regime of the Deliverables under the Appraisal Contract. Man in India, 97(25), 2017, pp. 357 364. 